\title{
Toronto 2008
}

\author{
By Brandon Wee
}

Fall 2008 Issue of KINEMA

HIGHLIGHTS FROM THE TORONTO INTERNATIONAL FILM FESTIVAL 2008

Reflecting tough economic times, Toronto's $33^{\text {rd }}$ annual edition presented a leaner program, substituting less films with multiple screenings as a trade off. Yet, this didn't deter criticism that the festival has gone to the dogs, with at least one local tabloid observer accusing it of elitism. Among this year's programme highlights: a stellar selection of Japanese titles represented across the festival's several sections, and a rare screening of a Lino Brocka film. Less compelling was the festival's inaugural commitment to the cinemas of Southeast Asia, for none of this year's representative Filipino and Thai titles were remarkable. Elsewhere however, there were exceptions:

Achilles and the Tortoise (Kitano Takeshi, Japan 2008)

Opening with a dramatic first act about Machisu, a boy whose dreams of being a painter are thwarted by the death of his rich parents, Kitano Takeshi's latest film then assumes a laconic second act as it charts his difficult growth into adulthood. The shift in tone - from elegant to kitschy - deliberately mirrors Machisu's struggles in art and life as he tries to achieve the impossible: originality. Droll yet thoughtful, this understated work personifies Kitano's musings on art and the role of the filmmaker as artist.

Aide-toi le ciel t'aidera (François Dupeyron, France 2007)

When an unexpected turn of events trips the working class Mousse family on their daughter's wedding day, Sonia, the film's central and maternal figure, decides it best to keep the news from her household of misfits while hatching a plan to keep up appearances with the help of an elderly neighbour. Félicité Wouassi leads an energetic ensemble in this effective black comedy that subtly observes the resident disaffection of France's banlieues; the film's title better translates as "God helps those who help themselves."

Un barrage contre le Pacifique (Rithy Panh, France-Cambodia-Belgium 2008)

Adapted from Marguerite Duras' 1950 eponymous novel and set in 1930s French Indochina, Rithy Panh's luscious, epic-like tale centres on a French widow and her two adolescent children. They struggle to make a living on a piece of non-arable paddy field which the colonial administration had deceived them into investing. Isabelle Huppert is at her usual stoic best, playing a weathered but shrewd matriarch who straddles her children's longing for freedom with her defiance for authority out to get rid her and other villagers.

Bayan Ko: Kapit sa Patalim (Lino Brocka, The Philippines 1984)

A tribute presentation to the late TIFF programmer, David Overbey and the films he championed, this rare screening of a Brocka film is social-realist melodrama at its best. Phillip Salvador plays a working class chap who accepts a salary advance from his boss for his wife's medical bill in exchange for waiving his right to strike. But a brush with bad company and a merciless social system soon provoke him to desperate measures. Translated as "My Country: Gripping the Knife's Edge," the film's run-in with the Marcos government is legendary.

Knitting (Yin Lichuan, China 2008)

Yin Lichuan follows her affecting 2007 inter-generational drama, The Park, with a look at a ménage à trois set in Guangzhou. Just as a charming young drifter and his girlfriend are settling down to eke out a meagre existence, his ex-girlfriend abruptly turns up at their door and insinuates herself into the couple's life. Territorial and character opposites, both women initially harbour resentment but soon learn that their best support is each other. Enhanced by moments of wicked humour, Yin delivers an captivating second film.

The Sky Crawlers (Oshii Mamoru, Japan 2008)

Set in a parallel universe inhabited by Kildren - adolescents blessed and cursed by eternal youth, Oshii's adaptation of Mori Hiroshi's novel centres on fighter pilots from an arms corporation who are tasked to annihilate their peers from a rival company. The catch is that all their actions and motivations are designed as theatrical entertainment for the masses. Carried along by impressive dogfight choreography and an 
elegiac Kawai Kenji score, this haunting interpretation is Oshii's critique of how the coincidence of youth and materialism is manipulative by nature.

Toronto Stories (Sook-Yin Lee, Sudz Sutherland, David Weaver, Aaron Woodley, Canada 2008)

After recent cinematic love-letter anthologies to the world's great urban jungles: Paris, Tokyo, and New York, Toronto is the latest city to crave affection; the difference is that the four filmmakers behind Toronto Stories are natives. Although distracted by a weak master narrative involving a mysterious boy linked to each story, every contribution is an intriguing encounter, with Sutherland's entry notable for being the most gripping and socially relevant. The only complaint about this project is that, in spite of its title, Toronto frankly underplays itself.

Tulpan (Sergey Dvortsevoy, Germany-Switzerland-Kazakhstan-Russia-Poland 2008)

After completing his naval service, Asa, a young man returns home to the dry Kazakh steppe and experiences culture shock. His desire to be a nomadic shepherd like his sister's family is frustrated by his brother-in-law's demand that he first find a wife, but the only women he desires on the steppe - Tulpan, and her family, continually spurn his proposals. Shot in hand-held, documentary fashion, Kazakh Sergey Dvortsevoy's first feature is also an intriguing anthropological study of a little-known place in Central Asia.

Vacation (Kadoi Hajime, Japan 2008)

An outstanding Japanese title this year, Kadoi Hajime's second film contrasts the emotional states of Kaneda, a prisoner awaiting his execution, and Hirai, a veteran prison guard who, for an incentive, volunteers to assist in the hanging despite marrying his fiancée the following day. Although not charged with an overt political statement, Kadoi has remarked during one post-screening discussion that the film is empathetic toward those civil servants burdened with certain unappealing aspects of their job - particularly in a country largely supportive of capital punishment.

Wendy and Lucy (Kelly Reichardt, USA 2008)

Kelly Reichardt's eponymous study of a single young woman and her dog living at the mercy of Murphy's Law while on a cross-country jaunt is just as likely to draw respectful indifference alongside the volume of muted enthusiasm it has since attracted for a story about human affection and the will to survive set in rich imageries of rural America. Michelle Williams' understated performance is supported by key roles from Wally Dalton as an sympathetic security guard and Will Paton as an unsympathetic car mechanic.

\section{Author Information}

Brandon WEE lives in Toronto. He has written for Asia Pacific Arts (Los Angeles), Cineaste (New York), Cinema Scope (Toronto), Ricepaper (Vancouver), and Senses of Cinema (Melbourne). 